\title{
KAJIAN IMPLEMENTASI PROGRAM WAJIB BELAJAR 12 TAHUN DI KOTA SURABAYA
}

\author{
Oleh: Ikhya Ulumudin*\&Sri Fajar Martono*
}

\begin{abstract}
This study aims to find out the strategy applied by Surabaya city in implementing the 12-year compulsory education program and the funding of school operational cost of secondary education. The approach used was both qualitative and quantitative with data and information gathered from interviews, Focus Group Discussion (FGD), and survey form. It can be concluded that the first strategy done by Surabaya city in supporting 12-year compulsory education was preparing a regulation support through a local government's (including the mayor's) laws and regulations, which mandate about educational financing. This educational budget is used in improving students' participation and competence, improving schools' infrastructure and facility, and improving educators and educational staffs' competence and welfare. The only sources of school operational cost funding for public secondary schools in Surabaya are the BOS grant from central government and BOPDA grant from local government, whereas for private schools, there is also support from the community in the form of committee contribution. The 12-year compulsory education program in Surabaya can be adopted as a best practice for other districts/cities who are implementing the program.
\end{abstract}

Keywords: Compulsory education, BOPDA, operational.

\section{PENDAHULUAN}

\section{A. Latar Belakang Masalah}

Faktor utama keberhasilan pembangunan di suatu negara adalah tersedianya Sumber Daya Manusia (SDM) yang bermutu. Upaya peningkatan mutu SDM tersebut bertitik tolak pada upaya pembangunan bidang pendidikan. Oleh karena itu pendidikan merupakan salah satu aspek yang sangat penting dalam pembangunan suatu negara.

\footnotetext{
*Peneliti pada Puslitjakdikbud, Balitbang Kemdikbud. E-mail: ikhya. puslitjak@gmail .com.
} -Peneliti pada Puslitjakdikbud, Balitbang Kemdikbud. E-mail: srifajarm@yahoo.com. 
Pembangunan pendidikan salah satunya dengan peningkatan program wajib beajar, yang semula wajib belajar 9 tahun menjadi 12 tahun. Rendahnya pertumbuhan ekonomi salah satunya disebabkan oleh rendahnya kualitas dan tingkat pendidikan masyarakat (Saripudin, 2005)

$$
\text { Kota Surabaya telah }
$$
mencanangkan program wajib belajar 12 tahun sejak tahun 2012. Program wajib belajar 12 tahun tersebut sejalan dengan visi dan misi dinas pendidikan Kota Surabaya. Visi dinas pendidikan kota Surabaya adalah menjadi barometer dan inspirator pendidikan nasional. Sedangkan misinya adalah peningkatan kompetensi guru, peningkatan kompetensi siswa, peningkatan kualitas sekolah, ketersediaan layanan yang bermutu. Melalui program peningkatan Wajib belajar diharapkan dapat meningkatan mutu SDM, sehingga dapat bersaing dengan negara tetangga, terutama untuk menghadapi Masyarakat Ekonomi Asean.

Dalam menyukseskan program wajib belajar 12 tahun, tentunya harus mempunyai anggaran pendidikan yang tinggi. Oleh karena itu, hal yang paling utama dan pertama kali dilakukan adalah menyiapkan peraturan perundangan terkait pendanaan pendidikan yang diterbitkan oleh daerah. Didalam peraturan perundangan tersebut, tentunya harus disebutkan secara eksplisit tentang pendanaan pendidikan yang ditanggung oleh pemerintah daerah.

Program yang perlu disiapkan dalam rangka implementasi wajib belajar 12 tahun adalah penambahan sarana prasarana, penambahan tenaga pendidik dan tenaga kependidikan, dan tentunya program bantuan biaya operasional untuk siswa. Sesuatu yang sering dilupakan dalam program Wajib belajar 12 tahun adalah dalam peningkatan mutu pendidikan. Oleh karena itu, didalam program wajib belajar 12 tahun jangan melupakan tentang peningkatan mutu pendidikan. Peningkatan mutu pendidikan dapat melalui program peningkatan kompetensi guru, peningkatan kualifikasi guru, program peningkatan mutu siswa dan lain-lain. 
Penelitian terkait wajib belajar 12 tahun jarang ditemukan, salah satunya adalah Penelitian yang dilakukan Indrawati (2009) dengan judul strategi dan model pengembangan wajib belajar 12 tahun di kabupaten bengkalis provinsi riau. Hasil penelitiannya adalah terdapat beberapa model pengembangan diantaranya: a) Pembangunan Unit Sekolah Baru berupa SMA/MA/SMK Reguler; b) Pelaksanaan Kegiatan Kelompok Belajar Paket C; c) Pelaksanaan Ujian Persamaan SMA; d) Pembangunan SMA Luar Biasa; dan e) Pembangunan SMA Terbuka. Sementara itu, penelitian terkait wajib belajar 12 tahun sebagai best practice belum ditemukan. Oleh karena itu dibutuhkan penelitian atau kajianbest practicekabupaten/kota yang sudah melaksanakan program wajib belajar 12 tahun, yang hasilnya sebagai bahan pelajaran bagi kabupaten/kota yang akanmengimplementasikannya. Untuk itu, dalam kesempatan iniakan dikaji terkait "Implementasi program wajib belajar 12 tahun di Kota Surabaya”.

\section{B. Tujuan Penelitian}

Tujuan dalam penelitian ini adalah untuk mengetahui strategi Kota Surabaya dalam menerapkan program wajib belajar 12 tahun dan untuk mengetahui besarnya pembiayaan operasional sekolah menengah di Kota Surabaya, diantaranya: pemanfaatan pembiayaan BOPDA Kota Surabaya, proporsi biaya operasional sekolah, dan besarnya biaya operasional persiswa pertahun.

\section{KAJIAN LITERATUR}

\section{A. Wajib Belajar}

Pengertian wajib belajar dalam peraturan pemerintah republik Indonesia nomor 47 tentang wajib belajaradalah program pendidikan minimal yang harus diikuti oleh warga Indonesia atas tanggungjawab pemerintah dan pemerintah daerah. Selain itu, wajib belajar berfungsi mengupayakan perluasan dan pemerataan kesempatan memperoleh pendidikan yang bermutu bagi setiap warga negara Indonesia.

Pembiayaan pendidikan dalam wajib belajar 12 tahun bukan merupakan tanggung jawab pemerintah 
saja, akan tetapi peran masyarakat juga dibutuhkan, kecuali masyarakat yang miskin. Hal ini sesuai penelitian yang dilakukan oeh Martono (2012) yang hasilnya, sekolah gratis dinilai dapat meningkatkan ketidaksetaraan sosial dalam masyarakat, konsep sekolah gratis diberlakukan bagi masyarkat miskin bukan untuk semua siswa. Selain itu, sekoah gratis juga tidak sepenuhnya dapat meningkatakan mutu lulusan hal ini sesuai dengan hasil penelitian Supardi dan Leonard, (2012) yang hasilnya adalah kebijakan sekolah gratis tidak berpengaruh terhadap prestasi belajar siswa.

\section{B. Manajeman}

Sarana

\section{PrasaranaPendidikan}

Pendidikan yang bermutu dapat dihasilkan melalui transformasi sebuah sistem pendidikan yang didukung oleh kompnen input yang bermutu pula. Salah satu komponen input tersebut adalah akses pendidikan atau lebih khususnya ketersediaan sarana prasarana, oleh karena itu manajemen sarana prasarana harus disiapkan secara matang. Secara umum tujuan manajemen sarana prasarana pendidikan adalah memberikan layanan secara profesional dalam rangka terselenggaranya proses pendidikan yang efektif dan efisien (Bafadal, 2004).

Untuk meningkatkan mutu pendidikan, penyediaan sarana dan prasarana pendidikan harus disiapkan secara matang dan terencana dengan baik. Manajemen sarana dan prasarana pendidikan disekolah meliputi analisis dan penyusunan kebutuhan, pengadaan, penyaluran, pemakaian dan pemeliharaan, inventarisasi dan penghapusan (Hermino, 2013).

\section{Mutu Pendidikan}

Mutu menjadi salah satu hal yang utama dalam pendidkan. Oleh karena itu, dalam program wajib belajar 12 tahun harus juga disiapkan peningkatan mutunya juga. Mutu adalah totalitas dari fitur-fitur dan karakteristik-karakteristik yang dimiliki oleh produk yang sanggup untuk memuaskan kebutuhan konsumen (Gasperz, 1997). Selain itu mutu adalah sebuah proses terstruktur 
untuk memperbaiki keluaran yang dihasilkan (Arcaro, 2007)

Terdapat lima dimensi pokok yang menentukan mutu penyelenggaraan pendidikan, yaitu: (i) Keandalan (reliability), yakni kemampuan memberikan pelayanan yang dijanjikan secara tepat waktu, akurat dan memuaskan. (ii) Daya tangkap (responsiveness), yaitu kemauan para tenaga kependidikan untuk membantu para peserta didik dan memberikan pelayanan dengan tanggap. Proses pembelajaran hendaknya diupayakan interaktif dan memungkinkan para peserta didik mengembangkan kapasitas, kreatifitas, dan kapabilitas. (iii) Seluruh tenaga kependidikan harus benar-benar kompoten di bidangnya, reputasi penyelenggaraan pendidikan yang positif di mata masyarakat, sikap dan perilaku seluruh tenaga kependidikan mencerminkan profesionalisme dan kesopanan. (iv) Empati, meliputi kemudahan dalam melakukan hubungan komunikasi yang baik antara murid dan guru. (v) Bukti langsung (tangible), meliputi fasilitas fisik, perlengkapan, tenaga kependidikan dan sarana komunikasi (Hikmat, 2009).

\section{METODOLOGI PENELITIAN}

Kajian ini menggunakan pendekatan kualitatif dan kuantitatif dengan metode survey. Metode survey digunakan untuk mendapatkan data dari tempat tertentu yang alamiah (bukan buatan), tetapi peneliti melakukan perlakuan dalam pengumpulan data, misalkan dengan mengedarkan kuesioner, wawancara, dan sebagainya (Sugiyono, 2011). Pendekatan kualitatif digunakan untukmencari data dan informasi terkait strategi Kota Surabaya dalam menerapkan program wajib belajar 12 tahun. Sedangkan pendekatan kuantitatif digunakanuntuk mengetahui pembiayaan operasional sekolah di Kota Surabaya, diantaranya pemanfaatan BOPDA Kota Surabaya, proporsi biaya operasional sekolah, biaya operasional peristiwa pertahun.

Lokasi penelitan berada di Kota Surabaya dan wakatu pelaksanaaan penelitian pada tanggal $16-19$ November 2015. Sampel penelitiannya 
terdiri dari dinas pendidikan Kota Surabaya serta delapan kepala dan bendahara sekolah menengah. Adapun sekolah sampelnya adalah SMA AlIrsyad Surabaya, SMA Ipiems Surabaya, SMAN 1 Surabaya, SMAN 18 Surabaya, SMK Kesehatan Surabaya, SMK PGRI 1 Surabaya, SMKN 6 Surabaya, SMKN 8 Surabaya.

Metode pengumpulan datanya menggunakan wawancara mendalam, FGD, dan daftar isian. Responden wawancara mendalam dilakukan dengan kepala bidang pendidikan menengahdinas pendidikan Kota Surabaya, sedangkan Responden FGD dilakukan dengan delapan kepala sekolah sampel, dan responden daftar isian adalah delapan bendahara sekolah sampel.

Teknik pengolahan dan analisis data menggunakan dua jenis yang dibedakan berdasarkan pendekatan. Pendekatan kualitatif menggunakan metode deskriptif analitis yang bersifat induktif, yaitu dengan mengidentifikasi, kemudian mengklasifikasikan strategi Kota Surabaya dalam implementasi program wajib belajar 12 tahundan selanjutnya menarik kesimpulan. Pendekatan kuantitatif menggunakan statistik deskriptif, yaitu dengan mempersentasekan pemanfaatan BOPDA Kota Surabaya dilihat dari jenis pengeluaran personalia dan non personalia, proporsi biaya operasional sekolah menengah Kota Surabaya, dan rerata biaya operasional persiswa pertahun real dan yang diharapkan oleh satuan pendidikan.

\section{HASIL PENELITIAN}

\section{Strategi Kota Surabaya dalam Menerapkan Program Wajib Belajar 12 Tahun}

Pendidikan menjadi sektor penting yang mendapat perhatian besar dari Pemkot Surabaya. Hal ini dapat dilihat dari pencananganwajib belajar 12 tahun sejak tahun 2012 yang berlandaskan Peraturan Daerah (Perda) Kota Surabaya No. 16 tahun 2012 tentang Pendidikan. Dalam pasal 16 Perda tersebut dinyatakan bahwa "Pemerintah daerah wajib menyediakan dana guna menuntaskan wajib belajar 12 tahun." Perda ini selanjutnya dikuatkan dengan 
Peraturan Walikota Kota Surabaya No. 47 Tahun 2013 tentang penyelenggaraan dan pengelolaan pendidikan di Kota Surabaya, pada pasal 16 yang berbunyi: "Pemerintah daerah menjamin terselenggaranya program wajib belajar minimal pada jenjang pendidikan dasar dan menengah". Tujuan program wajib belajar tersebut adalahmemberikan pendidikan minimal bagi warga Kota Surabaya untuk dapat mengembakan potensi dirinya agar dapat hidup mandiri di dalam masyarakat atau melanjutkan ke jenjang yang lebih tinggi.

Kebijakan Walikota Surabaya untuk menyukseskan wajib belajar 12 tahun didukung regulasi yang diaplikasikan dengan pendanaan yang relatif memadai. Komitmen pemerintah daerah Kota Surabaya tersebut dituangkan dalam besarnya anggaran pendidikan yang besar dan cenderung terus mengalami peningkatan dari tahun ke tahun. Pada tahun 2015, anggaran program pendidikan Kota Surabaya sebesar Rp 2,1 triliun dari $\mathrm{Rp} 7,2$ triliun APBD tahun 2015 atau mencapai 29,9 persen dari total APBD Kota Surabaya. Sedangkan tahun 2016 anggaran pendidikan meningkat menjadi Rp 2,35 triliun dari Rp 7,89 triliun APBD atau mencapai 31 persen dari total APBD 2016. (Lihat grafik 1)

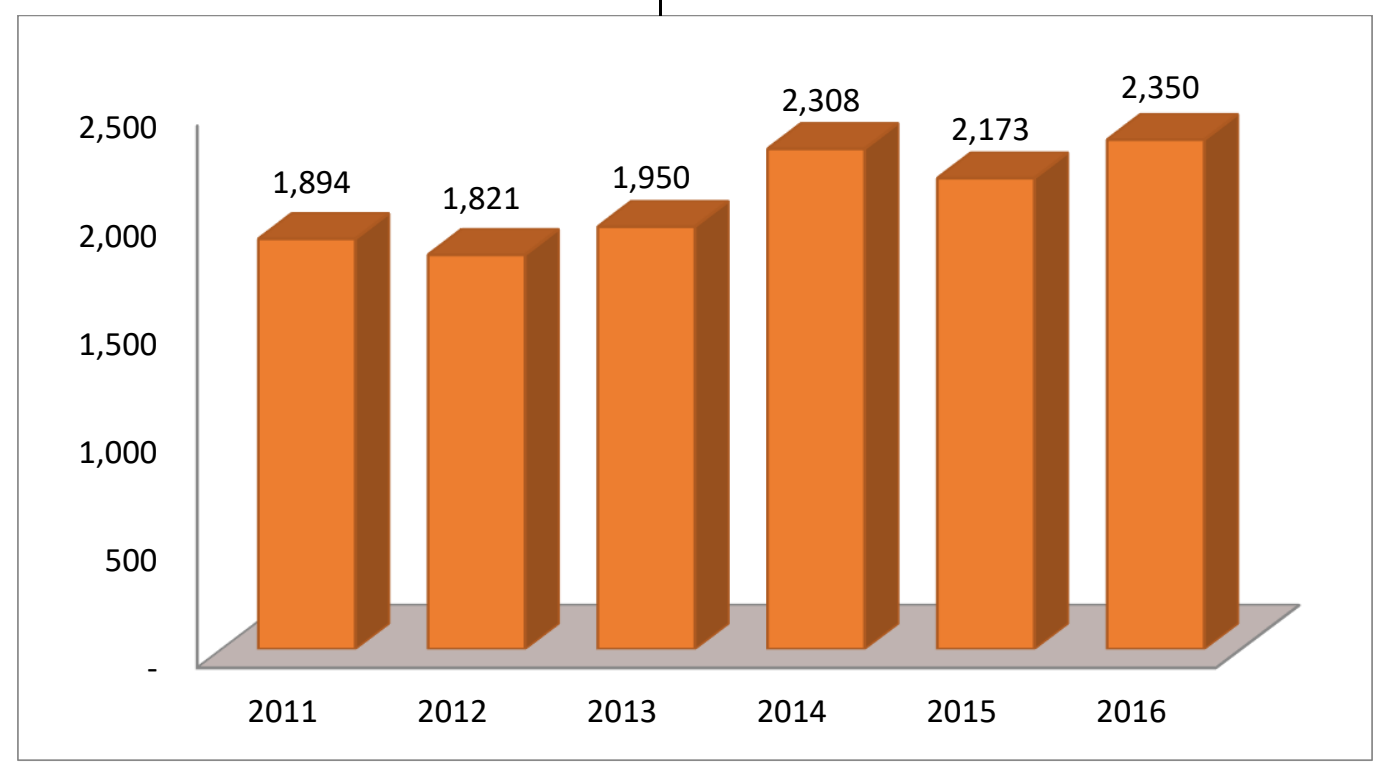




\section{Sumber: Data hasil penelitian diolah}

Grafik 1. Anggaran Pendidikan Kota Surabaya 2011 s. d 2016 (dalam milyar rupiah)

Dari dana tahun anggaran 2016 tersebut, belanja langsung mencapai RP. 1,1 triliun dan belanja tidak langsung mencapai 1,25 triliun. Dana tidak langsung digunakan untuk belanja pegawai, sedangkan belanja langsung digunakan untuk peningkatan mutu pendidikan seperti peningkatan kompetensi guru, penyediaan prasarana pendidikan, BOPDA dan lain-lain. BOPDA pada tahun 2016 sebesar 520 Milyar, yang terbagi atas $\mathrm{Rp} 315$ Milyar untuk jenjang pendidikan dasar kemudian Rp. 205 Milyar untuk pendidikan menengah. Besarnya anggaran BOPDA Jenjang SD persiswa dialokasikan Rp. 62. 500/siswa/bulan, SMP Rp. 118. 000/siswa/bulan, dan SMA dan SMK Rp. 152. 000/siswa/bulan (Seputar Indonesia, Kamis 26 November 2015).

Dengan bantuan BOPDA sekolah yang diselenggarakan Pemerintah Daerah dilarang memungut biaya operasional kepada orangtua. Untuk sekolah swasta boleh memungut dari orang tua siswa bila dana bantuan yang diberikan pemerintah melalui BOPDA lebih kecil daripada iuran komite yang sebelumnya diberlakukan sekolah. Misalkan SMKS Farmasi, iuran komite yang dipungut dari orang tua sebelumnya sebesar $\mathrm{Rp}$ 200. 000 setelah ada BOPDA menjadi Rp 48. 000 yang digunakan untuk menutup bantuan BOPDA tahun 2015 sebesar 152. 000/siswa/bulan baik di sekolah negeri maupun sekolah swasta. Namun sekolah yang diselenggarakan oleh masyarakat (sekolah swasta) yang telah menerima biaya operasional pendidikan daerah dari Pemda Kota Surabya tidak diperkenankan membebani biaya apapun kepada peserta didik yang berasal dari keluarga miskin.

Selain diberikan BOPDA, bagi siswa yang tidak mampu akanmendapatkan bantuan biaya personal untuk pembelian seragam 
sekolah, tas, sepatu, dan sejenisnya. Jumlah siswa yang menerima sebesar 5 persen dari total jumlah siswa baru yang diterima. Syarat mendapatkan bantuan tersebut harus mencantukan surat keterangan miskin atau tercatat dalam database data keluarga miskin pemerintah daerah. Bantuan tersebut sebesar Rp. 534. 600 untuk laki-laki dan 548. 300 untuk siswa perempuan bagi siswa sekolah menengah.

Setelah lulus SM, Pemda Kota Surabaya juga menyediakan program beasiswa untuk melanjutkan ke jenjang yang lebih tinggi berupa beasiswa bibit unggul. Program beasiswa bibit unggul diperuntukan bagi siswa miskin yang diterima di Universitas Aerlangga dan Institiut Teknologi Surabya (ITS). Tak hanya itu, pemkot juga menyediakan beasiswa khusus sekolah perawat dan pelayaran. Pemkot Kota Surabya sudah punya strategi untuk beasiswa spesial tersebut sehingga setiap pelajar yang lulus punya peluang kerja tinggi. Misalnya, perawat sengaja dipilih sebagai jurusan khusus penerima beasiswa karena melihat peluang lowongan pekerjaan di Yokohama
Jepang tengah butuh banyak tenaga kerja di bidang itu.

Oleh karena itu, para penerima beasiswa sekolah perawat sekaligus dibekali kemampuan berbahasa Jepang. Sedangkan lulusan sekolah pelayaran merupakan skill yang jarang dimiliki, padahal lulusan pelayaran sangat dibutuhkan mengingat Negara Indonesia merupakan negara kepulauan dan dua pertiganya adalah lautan. Hal ini terbukti dengan kenyataan bahwa siswa yang masih duduk di kelas pertama sudah inden atau dipesan oleh perusahaan untuk dipekerjakan. Dalam peningkatan kompetensi siswa terutam untuk menghadapi dunia kerja Pemda Kota Surabaya juga menyelenggarakan program pelatihan lifeskill bagi siswa.

Dalam kaitannya dengan peningkatan akses, anggaran pendidikan Kota Surabaya juga dimanfaatkan untuk peningkatan sarana prasarana terutama untuk pembangunan unit sekolah baru, renovasi sekolah, dan penyediaan sarana prasarana pembelajaran seperti peralatan praktikum dan teknologi informasi. Menurut Kabid Dikmen 
Kota Surabaya "Dengan anggaran sebesar 31 persen di sektor pendidikan, penyebaran dan daya tampung SM di kota surabaya sudah tidak ada masalah. Angka melanjutkan dari jenjang SMP ke jenjang SM sudah mencapai 100 persen".

Untuk meningkatkan kinerja guru, pemerintah Kota Surabaya juga memperhatikan kesejahteraan guru, salah satu bentuknya dengan pemberian tunjangan kinerja guru. Tunjangan kinerja guru dijalankan secara online melalui sistem kinerja guru, melalui situs www. kinerjasekolah. dispendik. surabaya. go. id. Sistem informasi kinerja guru merupakan sebuah bentuk penilaian diri sendiri yang dilakukan oleh seorang guru. Penilaian tersebut diwujudkan melalui tunjangan kinerja guru yang besarnya berbeda-beda sesuai dengan kinerjanya.

Strategi untuk meningkatkan kompetensi guru, Pemda Kota Surabaya mempunyai beberapa program salah satunya yaitu program delapan langkah pengembangan kompetensi guru, yang terdiri dari: Perubahan paradigm mengajar, penerapan 20 strategi mengajar, pendampingan pembuatan RPP, silabus, dan PTK, pendampingan MGMP/KKG dalam membuat bahan ajar, karya tulis ilmiah guru. Program peningkatan personalia tenaga pendidik lainnya yang dilakukan Pemda Kota Surabaya yaitu seleksi calon kepal sekolah dan calon pengawas online, Rotasi guru, pengiriman delegasi keluar negeri, beasiswa sekolah, dan lain-lain.

Program dan kegiatan yang dilakukan Pemda Kota Surabaya dalam rangka mendukung pelaksanaan implementasi wajib belajar 12 tahun dapat disimpulkan berhasil. Salah satu indikatornya adalah persentase angkatan kerja di Provinsi Jawa Timur berkualifkasi pendidikan tinggi yang tertinggi adalah di Kota Surabaya (Kemdikbud, 2014).

\section{Pembiayaan}

Operasional

Sekolah di Kota Surabaya

\section{a. Pemanfaatan BOPDA Kota Surabya}

Pemanfaatan BOPDA Kota Surabaya tertuang dalam peraturan Walikota Surabaya nomor 69 tahun 
2014 tentang petunjuk teknis pemberian hibah biaya pendidikan daerah. Dalam pasal 5 disebutkan bahwa belanja hibah biaya operasional pendidikan daerah digunakan untuk 14 komponen diantaranya pembelian alat tulis sekolah, biaya bahan dan alat habis pakai, pemeliharaan dan perbaikan ringan, biaya transport, biaya konsumsi, biaya pembinaan iswa/ekstrakurikuler biaya uji kompetensi, biaya praktek kerja industry, biaya pelaporan, biaya peningkatan mutu pendidik dan tenaga kependidikan, biaya pengembangan kurikulum, pembelian/pengadaan sarana dan prasarana pembelajaran, biaya daya dan jasa, biaya upah/honorarium tenaga pendidik dan tenaga kependidikan non Pegawai Negeri Sipil (PNS).

Pemanfaatan BOPDA Kota Surabaya dapat dibedakan menjadi biaya operasional persnonali dan biaya operasional non personalia. Pembiayaan operasional personalia dalam pemanfaatan BOPDA Kota Surabaya terdiri dari satu komponen, yakni upah/honorarium tenaga pendidik dan tenaga kependidikan non PNS. Sedangkan komponen sisanya dimanfaatkan untuk pembiayaan operasional non personalia. Berikut ini persentase pemanfaatan BOPDA Kota Surabaya berdasarkan jenis pengeluaran operasional personalia dan non personalia.

Tabel 1. Persentase pemanfaatan BOPDA Kota Surabaya dilihat dari jenis pengeluaran personalia dan non personalia.

\begin{tabular}{|c|l|c|c|c|}
\hline $\begin{array}{c}\text { N } \\
\text { O }\end{array}$ & \multicolumn{1}{|c|}{ NAMA SEKOLAH } & $\begin{array}{c}\text { PERSONALI } \\
\text { A }\end{array}$ & $\begin{array}{c}\text { NON } \\
\text { PERSONALI } \\
\text { A }\end{array}$ & $\begin{array}{c}\text { TOTAL } \\
\text { BOPDA }\end{array}$ \\
\hline 1 & $\begin{array}{l}\text { SMA AL-IRSYAD } \\
\text { SURABAYA }\end{array}$ & 63.94 & 36.06 & $270,864,000$ \\
\hline 2 & $\begin{array}{l}\text { SMA IPIEMS } \\
\text { SURABAYA }\end{array}$ & 38.34 & 61.66 & $1,362,528,000$ \\
\hline 3 & SMAN 1 SURABAYA & 25.34 & 74.66 & $1,351,584,000$ \\
\hline 4 & SMAN 18 SURABAYA & 33.33 & 66.67 & $1,218,432,000$ \\
\hline
\end{tabular}




\begin{tabular}{|c|l|c|c|c|}
\hline $\begin{array}{c}\text { N } \\
\text { O }\end{array}$ & \multicolumn{1}{|c|}{ NAMA SEKOLAH } & $\begin{array}{c}\text { PERSONALI } \\
\text { A }\end{array}$ & $\begin{array}{c}\text { NON } \\
\text { PERSONALI } \\
\text { A }\end{array}$ & $\begin{array}{c}\text { TOTAL } \\
\text { BOPDA }\end{array}$ \\
\hline 5 & $\begin{array}{l}\text { SMK KESEHATAN } \\
\text { SURABAYA }\end{array}$ & 12.43 & 87.57 & $261,564,900$ \\
\hline 6 & $\begin{array}{l}\text { SMK PGRI 1 } \\
\text { SURABAYA }\end{array}$ & 71.35 & 28.65 & $1,061,001,000$ \\
\hline 7 & SMKN 6 SURABAYA & 46.40 & 53.60 & $4,072,952,841$ \\
\hline 8 & SMKN 8 SURABAYA & 41.52 & 58.48 & $2,665,119,101$ \\
\hline \multicolumn{2}{|l|}{ TOTAL } & 38.55 & 61.45 & $32,052,739,24$ \\
8
\end{tabular}

Sumber: Data hasil penelitan, diolah

Pemanfaatan BOPDA rata-rata di sekolah sampel untuk biaya operasional personalia sebesar $38,55 \%$, sedangkan untuk biaya operasional non personalia sebesar $61,45 \%$. Pemanfaatan untuk biaya operasional personalai terbesar adalah SMK PGRI Surabaya yakni $71,35 \%$ dan diikuti oleh SMA AlIrsyad Surabaya sebesar 63,94\%. Hal ini merupakan wajib belajar mengingat mayoritas bahkan seluruh tenaga pendidik dan kependidikan merupakan non pegawai negeri sipil. Namun ada sekolah negeri dalam pemanfaatan BOPDA untuk biaya operasional personalia relatif besar seperti SMKN 6 Surabaya $46,40 \%$ dan SMKN 8 Surabaya 41,52\%. Dilain sisi, ada sekolah dalam memanfaatkan BOPDA biaya operasional personalinya relatif kecil, seperti SMK Kesehatan Surabaya sebesar $12,43 \%$.

Melihat dari keragaman pemanfaatan BOPDA untuk biaya operasional personalia, pemerintah Kota Surabaya hendaknya memberikan peraturan yang lebih rijit dan jelas terkait pemanfaatan BOPDA untuk biaya upah/honorarium tenaga pendidik dan tenaga kependidikan non pegawai negeri sipil, sehingga pemanfaatannya dapat efektif dan efisien. Untuk itu, dalam peraturan Walikota Surabaya terkait petunjuk teknis pemberian hibah biaya pendidikan daerah, khususnya untuk BOPDA diberikan penjelasan mengenai rambu-rambu pemanfaatannya.

$$
\text { Misalnya, }
$$


pemanfaatan untuk upah/honorarium tenaga pendidik dan tenaga kependidikan non pegawai negeri sipil diberikan batas persentase dalam penggunaannya. Selain itu, ada batas minimal dan maksimal dalam pemberian honor yang mengacu pada Upah Minimal Regional (UMR) Kota Surabaya.
Biaya operasional sekolah di Kota Surabaya untuk sekolah menengah negeri bersumber dari BOS Pusat dan BOPDA, sedangkan untuk sekolah swasta selain bersumber dari BOS Pusat dan BOPDA ada juga kontribusi dari masyarakat yaitu dari iuran komite atau sejenisnya. Berikut ini grafik proporsi biaya operasional sekolah menengah di Kota Surabaya.

\section{b. Proporsi Biaya Operasioanal Sekolah}

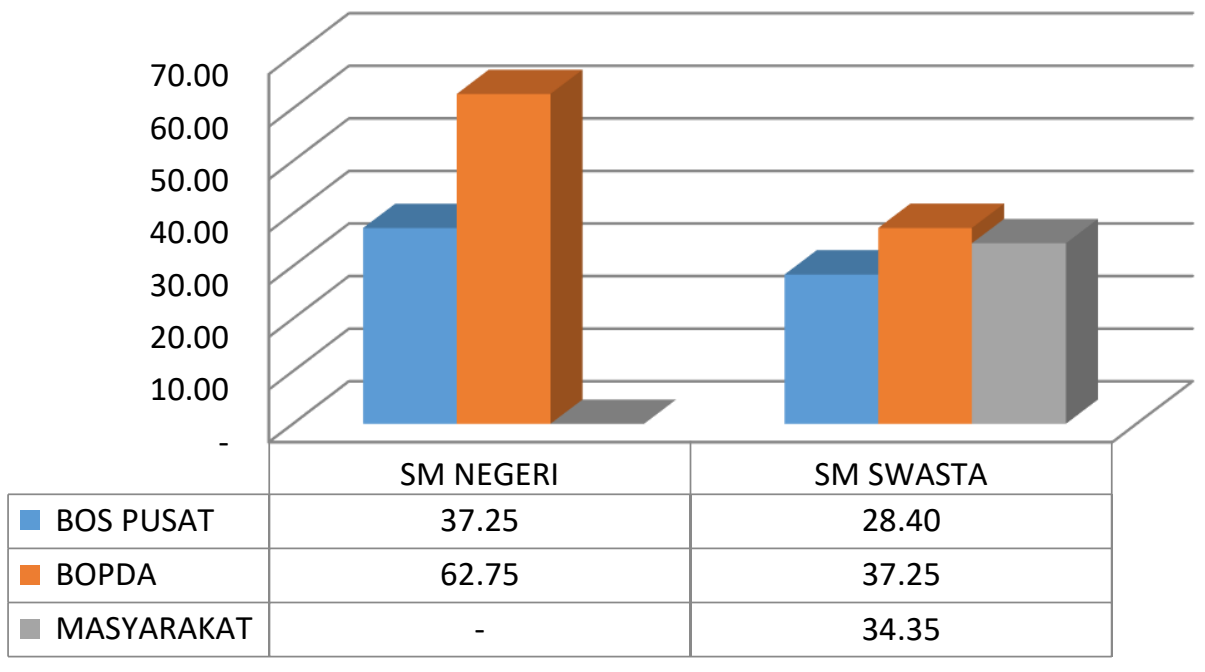

Sumber: Data hasil penelitan diolah

Grafik 2. Proporsi Biaya Operasional Sekolah Menengah Kota Surabaya

Pada grafik 2 diatas, menunjukkan kebutuhan biaya operasional sekolah menengah negeri yang bersumber dari
BOS pusat sebesar 37,25 sedangkan dari BOPDA 62,75\%. Sementara kontribusi dari masyarakat tidak ada 
mengingat Kota Surabaya memberikan kebijakan menggratiskan/tanpa pungutan untuk wali murid dalam biaya operasional sekolah, khusunya sekolah negeri.

Berbeda dengan sekolah menengah negeri, sekolah menengah swasta diberi kebesan untuk menarik iuran komite dari orangtua siswa dengan syarat biaya operasionalnya melebihi dari bantuan BOPDA, namun masyarkat yang miskin tidak boleh sama sekali di tarik iuran komite atau sejenisnya. Kontribusi BOS pusat dalam biaya operasional sekolah menengah swasta sebesar 28,40\%, Sedangkan dari BOPDA Kota Surabaya sebesar $37,25 \%$, sementara itu dari masyarakat yang bersumber dari iuran komete dan sejenisnya sebesar $34,35 \%$.

\section{c. Biaya Operasional Persiswa Pertahun}

Biaya operasional persiswa pertahun sekolah menenengah di Kota Surabaya untuk sekolah negeri sebesar 2,9 juta persiswa pertahun sedangkan untuk sekolah swasta sebesar 3,8 juta persiswa pertahun. Namun menurut hasil FGD dan daftar isian, jumlah tersebut merupakan biaya minimal dengan kegiatan dan program yang biasa saja. Oleh karena itu, dibutuhkan anggaran operasional yang lebih tinggi untuk meningkatkan kualitas sekolah (Lihat grafik 3)

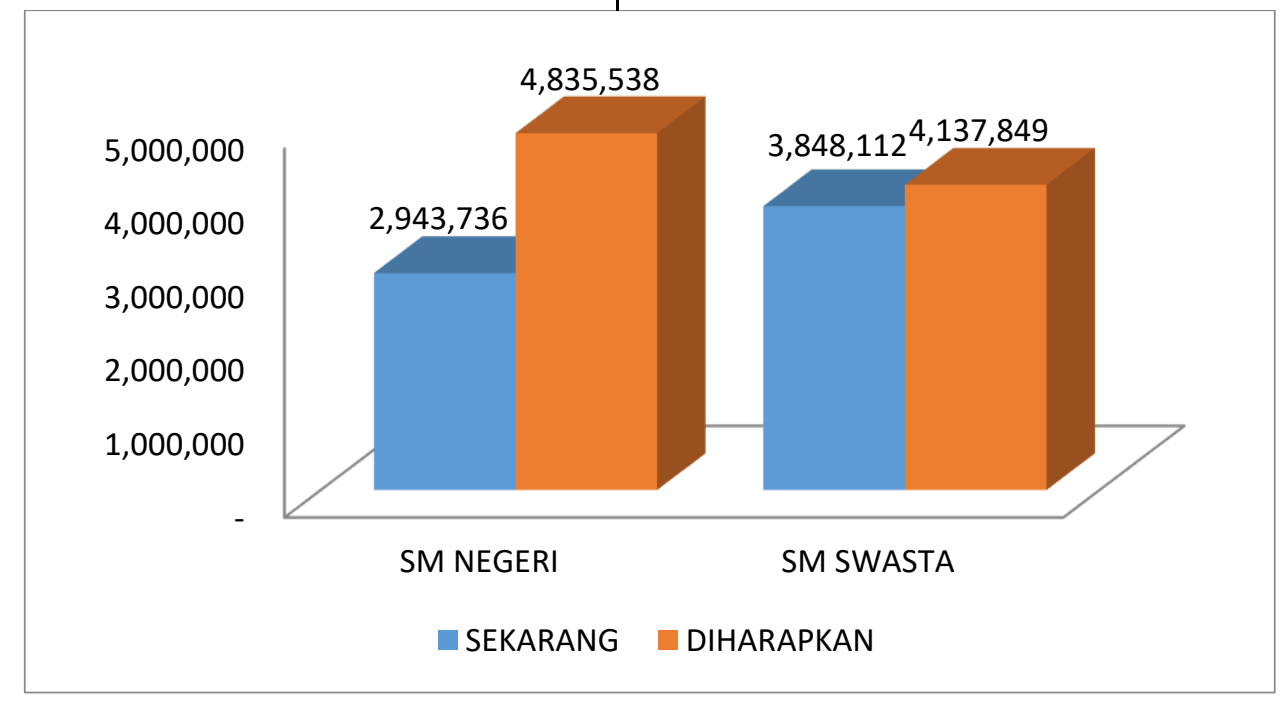


Sumber: Data hasil penelitan diolah

Grafik 3. Biaya Operasional Per Siswa Pertahun Real dan yang Diharapkan

Dari daftar isian didapat, bahwa biaya operasional siswa yang ideal untuk sekolah menengah negeri sebesar 4,8 juta dan sekolah menengah swasta sebesar 4,1 juta. Kenaikan tersebut mayoritas disebabkan karena untuk memenuhi pembiayaan yang dinilai masih kurang terutama pada komponen kelengkapan pembelajaran seperti penyediaan Infokus, Laptop, CCTV. Selain itu juga dari komponen pengembangan diri/ekstrakulikuler, honor guru non pegawai negeri sipil dan tambahan kinerja guru seperti walikelas, piket dan lain-lain.

\section{SIMPULAN DAN SARAN}

\section{A. Simpulan}

1. Strategi Kota Surabaya dalam

Menerapkan Program Wajib

Belajar 12 Tahun

Kota Surabaya dalam implementasi program Wajib belajar 12 tahun yang pertama kali dilakukan adalah menyiapkan regulasi dengan membuat Perda No. 16 tahun 2012 tentang pendidikan. Selanjutnya membuat Perwali No. 47 Tahun 2013 tentang penyelenggaraan dan pengelolaan pendidikan di Kota Surabaya. Kedua peraturan tersebut mengamanatkan Pemda wajib menyediakan dana guna menuntaskan wajib belajar 12 tahun. Berdasarkan peraturan tersebut, Pemda Kota Surabaya mengalokasikan pendanaan pendidikan mencapai $31 \%$ pada tahun 2016. Anggaran pendidikan tersebut digunakan untuk peningkatan partisipasi dan kompetensi siswa, peningkatan sarana prasarana sekolah, dan peningkatan kompetensi dan kesejahteraan PTK.

Program peningkatan partisipasi dan kompetensi siswa diantaranya melalui program BOPDA, bantuan bagi siswa miskin berupa seragam dan peralatan sekolah, program beasiswa bibit unggul, pelatihan lifeskill bagi siswa, dan lain-lain. Sementara peningkatan sarana prasarana sekolah melalui pembangunan unit sekolah baru, renovasi sekolah, penyediaan 
sarana prasarana pembelajaran seperti praktikum dan teknologi informasi. Sedangkan peningkatan kompetensi dan kesejahteraan PTK melalui pemberian tunjangan kinerja guru, program pengembangan kompetensi guru, seleksi calon kepal sekolah dan calon pengawas online, pengiriman delegasi keluar negeri, beasiswa sekolah, dan lain-lain. Dengan setrategi tersebut, Kota Surabaya dalam mensukseskan Wajib belajar 12 tahun dinilai berhasil. Indikator lain adalah bahwa persentase angkatan kerja di Provinsi Jawa Timur berkualifkasi pendidikan tinggi yang tertinggi adalah di Kota Surabaya. (Kemdikbud, 2014)

2. Pembiayaan Operasional Sekolah di Kota Surabaya

Pemanfaatan BOPDA Kota Surabaya terdiri dari 14 komponen. Pemanfaatan BOPDA Kota Surabaya dapat dibedakan menjadi biaya operasional persnonali dan biaya operasional non personalia. Pembiayaan operasional personalia dalam pemanfaatan BOPDA Kota Surabaya terdiri dari satu komponen, yakni upah/honorarium tenaga pendidik dan tenaga kependidikan non pegawai negeri sipil. Sedangkan komponen sisanya dimanfaatkan untuk pembiayaan operasional non personalia. Pemanfaatan BOPDA ratarata di sekolah sampel untuk biaya operasional personalia sebesar $38,55 \%$, sedangkan untuk biaya operasional non personalia sebesar $61,45 \%$.

Biaya operasional sekolah di Kota Surabaya untuk sekolah menengah negeri bersumber dari BOS Pusat dan BOPDA, sedangkan untuk sekolah swasta selain bersumber dari BOS Pusat dan BOPDA ada juga kontribusi dari masyarakat yaitu dari iuran komite atau sejenisnya. Biaya operasional sekolah menengah negeri yang bersumber dari BOS pusat sebesar 37,25 sedangkan dari BOPDA 62,75\%. Sementara Kontribusi BOS pusat dalam biaya operasional sekolah menengah swasta sebesar 28,40\%, dari BOPDA Kota Surabaya sebesar 37,25\%, dari masyarakat yang bersumber dari iuran komete sebesar 34,35\%.

Biaya operasional persiswa pertahun sekolah menenengah di Kota Surabaya untuk sekolah negeri saat ini 
sekitar 2,9 juta persiswa pertahun sedangkan untuk sekolah swasta sekitar 3,8 juta persiswa pertahun. Sedangkan menurut satuan pendidikan, biaya operasional siswa yang ideal untuk sekolah menengah negeri sekitar 4,8 juta dan sekolah menengah swasta sekitar 4,1 juta.

\section{B. Saran}

1. Strategi pemerintah daerah Kota Surabaya dalam mengimplementasikan program wajib belajar 12 tahun dinilai berhasil. Hal ini dapat dilihat dari peningkatan partisipasi dan kompetensi siswa, peningkatan sarana prasarana sekolah, dan peningkatan kompetensi dan kesejahteraan PTK. Outcomenya pun dapat dikatakan berhasil hal ini diindikasikan dari persentase angkatan kerja di Provinsi Jawa Timur berkualifkasi pendidikan tinggi yang tertinggi adalah di Kota Surabaya. Oleh karena itu, strategi Kota Surabaya dalam mengimplementasikan program wajib belajar 12 tahun dapat digunakan sebagai model atauBest Practice.
2. Terkait dengan kesejahteraan PTK honorer diharapkan dalam petunjuk teknis pemberian BOPDA diberikan penjelasan yang lebih rijit mengenai rambu-rambu pemanfaatan untuk upah/honorarium tenaga pendidik dan tenaga kependidikan non pegawai negeri sipil diberikan batas persentase dalam penggunaannya. Selain itu, ada batas minimal dan maksimal dalam pemberian honor yang mengacu pada Upah Minimal Regional (UMR) Kota Surabaya.

\section{DAFTAR PUSTAKA}

Arcaro, Jerome S. 2007. Pendidikan berbasis mutu. Yogyakarta: Pustaka Pelajar

Bafadal, Ibrahim. 2008. Menejemen perlengkapan sekolah: teori dan aplikasinya. Jakarta: Bumi Aksara

Gasperz, Vincent. 1997. Manajemen Kualitas dalam 


\section{JURNAL ILMIAH MIMBAR DEMOKRASI}

VOLUME 16. NOMOR 2. APRIL 2017

Jurnal pendidikan dan

Hermino, Agustinus. 2013. Asesmen kebutuhan organisasi persekolahan: tinjauan perilaku organisasi menuju comprehensive multilevel planning. Jakarta: Gramedia pustaka utama

Hikmat, 2009. Manajemen pendidikan. Bandung: Pustaka Setia.

Indrawati, Henny. 2009. Strategi dan model pengembangan wajib belajar 12 tahun di Kabupaten Bengkalis Provinsi Riau. Bandung: Jurnal Unpad volume 11 nomor 2

Kemdikbud. 2014. Peta kondisi pendidikan menengah universal propinsi Jawa Timur. Jakarta: Sekretariat jenderal pendidikan menengah.

Martono, Nanang. 2012. Perspektif konflik sekolah gratis atau sekolah dibantu BOS: Sebuah evaluasi kebijakan. Balitbang: kebudayaan.

Peraturan Daerah Kota Surabaya No. 16 tahun 2012 tentang Pendidikan.

Peraturan Walikota Kota Surabaya No. 47 Tahun 2013 tentang Penyelenggaraan dan pengelolaan pendidikan di Kota Surabaya

Peraturan Pemerintah Republik Indonesia Nomor 47 Tentang Wajib Belajar

Saripudin. 2005. Pengaruh Perumbuhan Ekonomi Sektoral Terhadap Kualitas Pendidikan. Tesis: Fakultas Ekonomi, Universitas Indonesia.

Sugiyono. 2011. Metode penelitian pendidikan. Bandung: Alfabeta

Supardi dan Leonard, (2012). Menakar keberhasilan pelaksanaan kebijakan sekolah gratis di DKI Jakarta. Balitbang: Jurnal pendidikan dan kebudayaan 